\title{
The Brazilian Chemical Society (SBQ) and the Chemistry Teaching in High Schools
}

"Brazil is the 15th in scientific production, having surpassed many countries with a greater tradition in research and human resource formation", has been recently stated by Mr. Jorge Guimarães, the Brazilian Federal Agency for Support and Evaluation of Graduate Education (CAPES) President.

There is no doubt many graduate programs have equaled the most important international research centers in their excellence levels. The same happens in the chemistry field. The excellence of some graduate programs is internationally recognized. If graduate schools are doing well, the same can not be said about the chemistry undergraduate level, though. The demand for chemistry courses is low and our great challenge is to show young students that the chemical career is financially and professionally worthwhile. Changing this situation should be on the Brazilian Chemical Society (SBQ) agenda.

In Brazil there are good examples of scientists' commitment to the formation of science teachers and both elementary and high school students that resulted in a greater demand for biology undergraduate courses and, as a consequence, better qualified graduates for the graduate programs in the field.

One of the most successful projects in Brazil has been supervised, since the second half of the 80's, by Professor Leopoldo de Meis, from the Medical Biochemistry School of the Federal University of Rio de Janeiro (UFRJ). This project has spread to 13 other public universities, involving 16 research groups that offer vacation courses and science education projects. Needless to say the Medical Biochemistry School program scores 7, the highest possible, according to CAPES standards.

The teaching of chemistry cannot do without school labs. Labs are the appropriate place for experiments, measurements, observations and minor experimental projects. Teaching chemistry out of the lab is the same as teaching how to swim out of the water.

The establishment of labs in high schools is not a simple task, because more important than the lab itself is the presence of motivated and well qualified teachers to make use of them for teaching. In this respect, the Brazilian Chemical Society (SBQ) has much to contribute. It can lead a large movement to encourage its members, mainly teachers and graduates, to offer vacation courses for both teachers and elementary / high school students as well as committing themselves to equip and supervise these school labs.

We know there are some specific initiatives in Brazil and that some research funding agencies support high school projects, but much more can be done. The Brazilian Chemical Society (SBQ) can, for example, set up the Chemistry Teacher Portal displaying such initiatives on the net and making simple experiments, with different degrees of difficulty available for teachers, to be executed in schools, under the supervision of graduates, oriented by their advisors. These works should be catalogued and their results continually evaluated. Besides that, the Brazilian Chemical Society (SBQ) should encourage science fairs, competitions and chemistry olympics. But, independently of what the Brazilian Chemical Society (SBQ) can do, why does not each CNPq (National Council for Technological and Scientific Development) productivity scholarship holder adopt a public high school lab? Undergraduate schools are the golden goose of graduate schools and one can not do without the other. In order to improve the undergraduate level, all possible efforts should be focused on the qualification of elementary and high school teachers.

The improvement of elementary education in Brazil and, particularly, of science teaching does not depend solely upon the national, state or local governments, but is the responsibility of researchers, scientific societies and, concerning chemistry, industries and industrial businessmen, as well. It concerns the government, above all, to invest more in education, but it is civil society's duty to demand transparency concerning these investments.

It is up to the SBQ, which assembles more than 3000 chemists in Brazil, to organize and encourage a "revolution" in the chemistry teaching in schools. It is never too late to encourage those who are concerned about education. It is never too late to teach and learn with pleasure.

Angelo C. Pinto (UFRJ) JBCS Editor 